\title{
Impact of Land Use/Land Cover Changes on the Thermal Environment in Urbanization: A Case Study of the Natural Wetlands Distribution Area in Minjiang River Estuary, China
}

\author{
Huizhen Zheng ${ }^{1}$, Yanhong Chen ${ }^{2,3}$, Wenbin Pan ${ }^{1}$, Yuanbin Cai ${ }^{1 *}$, Zijie Chen ${ }^{4}$ \\ ${ }^{1}$ College of the Environment and Resources, Fuzhou University, Shangjie Town, Minhou County, Fuzhou, Fujian, China \\ ${ }^{2}$ Fuzhou University Zhicheng College, Gulou District, Fuzhou, Fujian, China \\ ${ }^{3}$ College of Geographical Sciences, Fujian Normal University, Cangshan District, Fuzhou, Fujian, China \\ ${ }^{4}$ Fujian Environmental Protection Design Institute Co., Ltd., Jin’an District, Fuzhou, Fujian, China
}

Received: 10 June 2018

Accepted: 24 July 2018

\begin{abstract}
Under accelerated urbanization and high-intensity human activities, the natural wetlands distribution area (NWDA) in Minjiang River estuary faces the great challenge of a deteriorative urban thermal environment. This work aims to analyze the impact of land use/land cover (LULC) on the urban thermal environment and model wetland surface temperature disturbance characteristics during the process of urbanization. The study utilized the following methodological steps: (1) mapping of LULC spatial and temporal distribution through photo interpretation; (2) applying the mono-window algorithm to obtain the spatiotemporal patterns of land surface temperature (LST); (3) examining the correlation between LST and different LULC classes, normalized difference vegetation index (NDVI), normalized difference moisture index (NDMI), and normalized difference impervious surface index (NDISI); and (4) exploring wetland surface temperature characteristics based on profile analysis and regression models. The results showed that the LST pattern depended on the LULC distribution; the high LST zones were mainly observed in the center of Fuzhou city, and the low LST zones were mainly observed in forest and river areas. Moreover, the urban thermal environment was influenced by both LULC classes and urban growth types. Finally, the positive relationship between LST and NDISI indicated an amplifying effect of the impervious surface for wetland surface temperature, while vegetation with high liquid water attenuated the regional high temperature. The obtained conclusions are expected to be beneficial in improving the design and management of the urban thermal environment.
\end{abstract}

Keywords: urbanization; land use/land cover; land surface temperature; wetland; Fuzhou

*e-mail: caiyuanbin82@163.com 


\section{Introduction}

Urbanization is a global issue, particularly in many developing countries such as China [1]. Data provided by the United Nations in 2014 show that 54\% of the world's population lives in cities, and the proportion is expected to reach $66 \%$ by 2050 [2]. Population growth demands additional space for living and ultimately causes the expansion of impervious surface areas [3]. It is clear that fundamental changes in land use/land cover (LULC) have occurred over the past three decades and have inevitably resulted in a series of ecological and environmental problems, such as urban hydrology shift, urban heat island effect, biodiversity loss, and air pollution [4-5]. The thermal environment is a key part of the eco-environment; higher temperatures and extreme heat not only influence the comfort of urban residents but also increase energy consumption for cooling and compromise human health [6-9], threatening the sustainable development of cities.

Estuarine wetland ecosystem is one of the most evaluable ecosystems on earth because of the variety of goods and ecosystem services (e.g., flood regulation, water provision and purification, carbon fixation, habitat maintenance, and cooling effect) that wetlands offer to millions of people around the world [10-12]. However, numerous human activities have placed massive pressure on wetlands situated in adjoining urban areas, transforming natural wetlands into drained lands or impervious surface areas. The loss and degradation of wetlands has major consequences for the thermal environment and functions [13-14], causing habitat and species loss, soil pollution, rainfall interception change, and regulating ability damage [1516]. To date, few studies have provided insight into wetland surface temperature disturbance characteristics and quantitatively explored the combined impacts of various biophysical parameters on the wetland thermal environment.

Land surface temperature (LST) is a manifestation of the surface energy balance [17], which is widely used in identifying urban thermal environment dynamics. Traditionally, LST data is measured at in situ observation points, which is not an efficient method to present the whole region due to the limited local observation points and poor spatial resolution [18]. Fortunately, advances in satellite observation technology have provided a straightforward and consistent approach to monitor the extent and spatial pattern of LST [19-20]. At present, the common algorithms for LST inversion are atmospheric correction method, mono-window algorithm, split window algorithm, and single-channel algorithm [17]. The mono-window algorithm proposed by Qin et al. [21] has been demonstrated to be a simple and effective method for retrieving LST from thermal infrared bands.

Remotely sensed LST records the radiation energy emitted from the landscapes of the ground surface
[22], as different LULC types have diverse surface reflectance and roughness, causing differences in LST [17]. Cities are formed from sophisticated and spatially heterogeneous mosaics of different LULC classes that can produce different effects on thermal environments [23]. Many studies have examined the cooling effects of green space $[8,24]$ and water bodies [2], and proven that impervious surfaces significantly strengthen regional temperatures [25-26]. The impact of cropland on LST is not certain; Peng et al. [27] suggested that cropland mitigate the high temperature of Beijing, but Song et al. [28] demonstrated that there is a weak relationship between LST and cropland. There is still a paucity of literature on the role of natural wetlands in urban heating. Therefore, LULC is a vital element affecting LST, and the relationship between them should be investigated for the mitigation of urban thermal environment. Additionally, other indices, such as the normalized difference vegetation index (NDVI) [29-30], normalized difference moisture index (NDMI) [31-32], and normalized difference impervious surface index (NDISI) [33] have been confirmed as essential factors responsible for LST variations.

Analyzing the impact of LULC changes on a thermal environment needs to consider urban expansion [34]. Some researchers have explored the relationship between LST and urban expansion. Tu et al. [35] analyzed the spatial features of urban sprawl and surface urban heat island in eight directions in Nanjing. Tran et al. [34] revealed that every increase of $1 \%$ in urban area will increase surface temperature between 0.075 and $0.108^{\circ} \mathrm{C}$. Later, $\mathrm{Li}$ et al. [36] found a significant positive relationship between surface urban heat island and urban area size, and confirmed the enhanced heating effect of urban expansion. Nevertheless, few detailed studies about the effect of urban growth types on thermal environment have been conducted. Urban growth currently proceeds in different ways, such as infilling, edge-expansion, or outlying [37]. It is meaningful to understand how the thermal environment is affected by different urban growth types, which can contribute to developing sustainable cities for the general population.

Taking the natural wetlands distribution area (NWDA) in the Minjiang River Estuary as a study case, this study investigated the dynamics of land use/land cover and the thermal environment under urbanization. The objectives of this research are as follows: (1) to explore the spatiotemporal changes of LULC and LST in the urbanization process from 1993 to 2013, with a particular focus on the relationship between LST and LULC classes; (2) to examine the effects of urban sprawl and different urban growth types on the thermal environment; and (3) to analyze the impact of urban expansion on wetlands and estimate wetland surface temperature by applying ridge regression models. The results from this study will offer a scientific basis for urban planners and decision makers in mitigating thermal effects and protecting wetlands. 


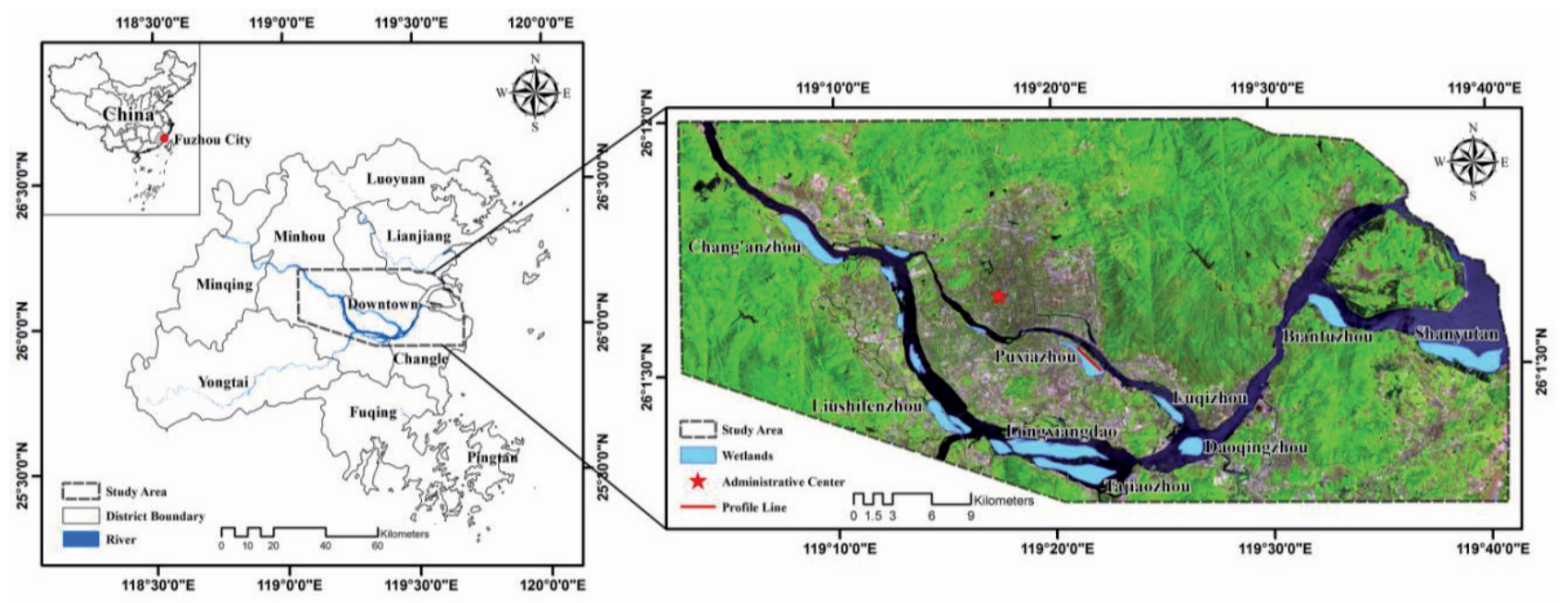

Fig. 1. Location of the study area.

\section{Material and Methods}

Study Area

The study area, the natural wetlands distribution area (NWDA), is located in the Minjiang River estuary basin surrounded by mountainous terrain $\left(25^{\circ} 56^{\prime}-26^{\circ} 12^{\prime} \mathrm{N}, 119^{\circ} 02^{\prime}-119^{\circ} 41^{\prime} \mathrm{E}\right)$ (Fig. 1). Situated in Fuzhou city of southeastern China, the NWDA has witnessed rapid and continuous urbanization that not only posed serious threats to the sustainability of wetlands but also caused a remarkable impact on the regional thermal environment. Data released by the National Climate Center in 2012 showed that Fuzhou was China's second hottest city. In 2013, Fuzhou experienced extreme high temperatures (maximum air temperature of $40.6^{\circ} \mathrm{C}$ ) in summer, and the annual number of hot days (air temperature $\geq 35^{\circ} \mathrm{C}$ ) reached 61 . Hence, the NWDA is selected as a representative area for this study.

The NWDA has a coverage area of $1604.36 \mathrm{~km}^{2}$ and a wetland area of approximately $30 \mathrm{~km}^{2}$. Shanyutan, Bianfuzhou, Daoqingzhou, Puxiazhou, Longxiangdao, Tajiaozhou, Liushifenzhou, Chang'anzhou, and other wetlands compose an ecological wetland chain of Minjiang River estuary. This region has a subtropical monsoon climate with a mean annual precipitation of 900-2100 $\mathrm{mm}$ and an average long-term annual temperature of $23^{\circ} \mathrm{C}$. By the end of 2016, the permanent resident population of the NWDA was 2.68 million.

\section{Data Sources}

Landsat 5 Thematic Mapper (TM) and Landsat 8 Operational Land Imager/Thermal Infrared Sensor (OLI/TIRS) images (Table 1) with Path/Row of 119/42 were downloaded from the United States Geographical Survey website (http://www.usgs.gov). Landsat data were selected due to adequate archival data, ease of access and performance in land cover classification, and temperature analysis demonstrated in previous studies [38]. In order to avoid the impact of seasonality, images obtained in the summer (from June to August) were used. All images were acquired in clear atmospheric conditions; the relevant meteorological data were collected from the China Meteorological Data Service Center database (http://data.cma.cn).

Table 1. Remote sensing data used in the study.

\begin{tabular}{|c|c|c|c|c|}
\hline Acquisition Dates & $\begin{array}{l}\text { Acquisition Time } \\
\qquad(\mathrm{GMT}+8)\end{array}$ & Sensors & Bands & Resolution (m) \\
\hline 26 June 1993 & $9: 55: 00$ & $\mathrm{TM}$ & $\begin{array}{c}3,4,5 \\
6\end{array}$ & $\begin{array}{c}30 \\
120 \times(30)\end{array}$ \\
\hline 29 June 2000 & 10:09:14 & $\mathrm{TM}$ & $\begin{array}{c}3,4,5 \\
6\end{array}$ & $\begin{array}{c}30 \\
120 \times(30)\end{array}$ \\
\hline 5 July 2008 & 10:19:41 & $\mathrm{TM}$ & $\begin{array}{c}3,4,5 \\
6\end{array}$ & $\begin{array}{c}30 \\
120 \times(30)\end{array}$ \\
\hline 4 August 2013 & $10: 32: 31$ & OLI/TIRS & $\begin{array}{c}4,5,6 \\
10\end{array}$ & $\begin{array}{c}30 \\
100 \times(30)\end{array}$ \\
\hline
\end{tabular}

$\times(30)$ Thermal band is acquired at different resolution, but products were resampled to $30 \mathrm{~m}$ resolution pixels. 
Table 2. Descriptions of land use/land cover classes of the study area.

\begin{tabular}{|c|c|}
\hline LULC Classes & Description \\
\hline Water & Mainly including sea, rivers, lakes, ponds, reservoirs and canals \\
\hline Forest/Grass & $\begin{array}{c}\text { Mainly including natural and semi-natural forestlands, shrub lands, forest nursery and lawn, } \\
\text { except wetland vegetation }\end{array}$ \\
\hline Cropland & Arable agricultural land, including paddy field, vegetable field, and dry lands \\
\hline Built-up land & Mainly including urban buildings, railways, roads and other impervious surfaces \\
\hline Wetland & $\begin{array}{c}\text { Transition zone between the land and water, mainly including natural or artificial, permanent, } \\
\text { or temporary marshes and peat bogs, as well as wetland vegetation and wetland water }\end{array}$ \\
\hline Bare land & Land without vegetation cover, mainly including exposed soil and landfill sites \\
\hline
\end{tabular}

The pre-processing included geographical registration, radiometric correction and atmospheric correction. Imagery preprocessing and data manipulation were performed with ERDAS IMAGINE 2015 and ENVI 5.1. Furthermore, ESRI ArcGIS 10.2 was employed for spatial analyses.

\section{Land Use/Land Cover Classification}

A maximum likelihood algorithm was chosen as the supervised classification method to obtain the LULC distribution in the study area. With reference to SPOT images and Google Earth, training samples of every LULC type were selected to acquire more accurate LULC classification maps. The major LULC classes were water, forest/grass, cropland, built-up land, wetland and bare land (Table 2). More than 200 independent samples were used to assess the accuracy
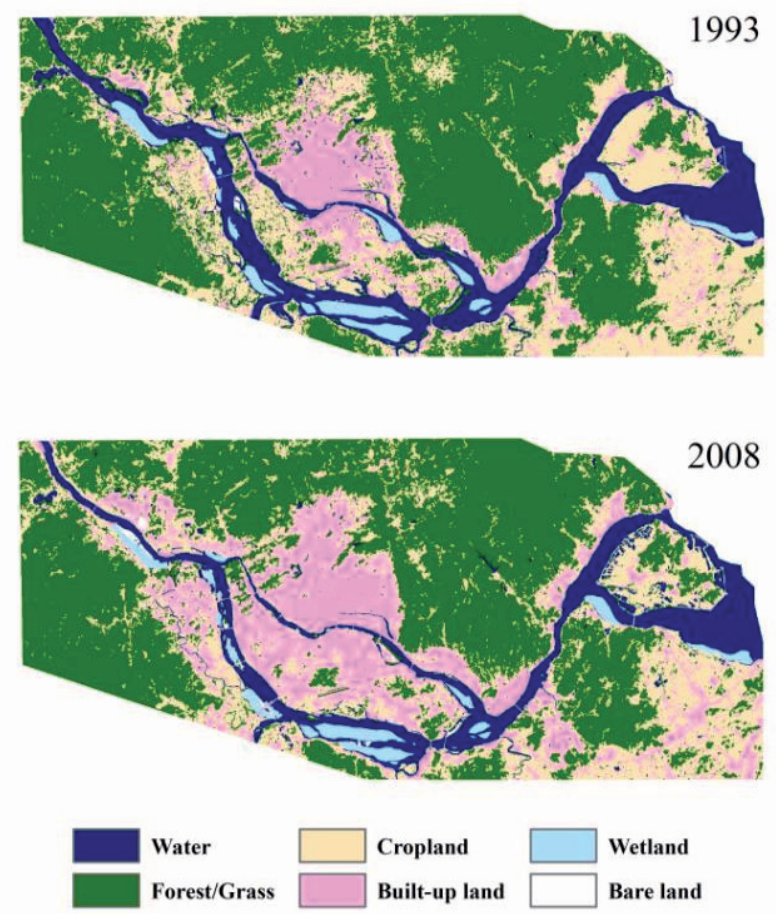

of each classified map, which were identified by visual interpretation. Fig. 2 shows the LULC maps of the NWDA for 1993, 2000, 2008, and 2013. The overall accuracies of these classified maps for the 1993, 2000, 2008 , and 2013 were $86.32 \%, 90.70 \%, 89.80 \%$, and $88.89 \%$, respectively; the kappa coefficients were 0.83 , $0.82,0.87$, and 0.86 , respectively. These data indicate that the LULC classification results are available for further study.

\section{Land Surface Temperature Retrieval}

Thermal infrared bands of Landsat 5 (Band 6) and Landsat 8 (Band 10) were used to estimate the LST of the study area. The Landsat 8 TIRS sensor has two thermal infrared bands (TIRS Bands 10 and 11), but the Landsat 8 official website recommends using TIRS Band 10 to retrieve LST because Band 11 has the
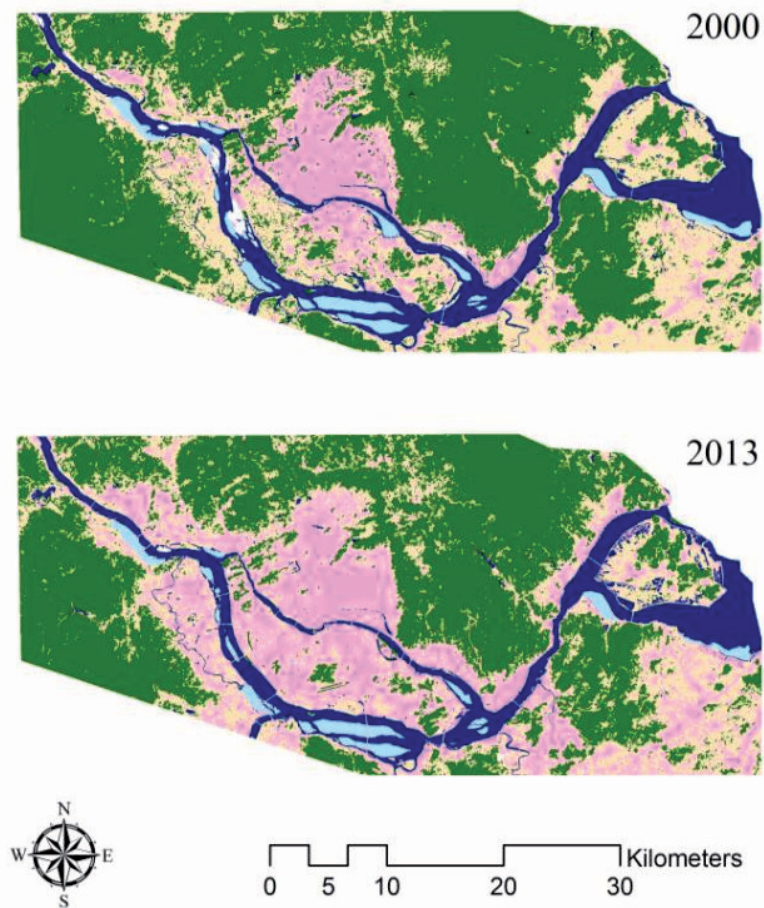

Fig. 2. LULC maps of the study area from 1993 to 2013. 
calibration problem of out-of-field stray light [39]. LST retrieval involves the following steps [40-41].

First, the digital number (DN) of the thermal infrared band was converted to spectral radiance using Eq. (1):

$$
L_{\lambda}=\text { gain } \times D N+\text { offset }
$$

...where $L_{\lambda}$ is the spectral radiance at the sensor's aperture in $\mathrm{W} \cdot \mathrm{m}^{-2} \cdot \mathrm{sr}^{-1} \cdot \mathrm{um}^{-1}$; gain is the rescaled gain in $\mathrm{W} \cdot \mathrm{m}^{-2} \cdot \mathrm{sr}^{-1} \cdot \mu \mathrm{m}^{-1}$, and offset is the rescaled bias in $\mathrm{W} \cdot \mathrm{m}^{-2} \cdot \mathrm{sr}$ ${ }^{1} \cdot \mu \mathrm{m}^{-1}$.

Second, spectral radiance was converted to the at-satellite brightness temperature using Eq. (2):

$$
T_{b}=\frac{K_{2}}{\ln \left(\frac{K_{1}}{L_{\lambda}}+1\right)}
$$

...where $T_{b}$ is the at-satellite brightness temperature in $\mathrm{K}$, and $K_{1}$ and $K_{2}$ are the pre-launch calibration constants. For Landsat $5 \mathrm{TM}, K_{1}$ is $607.76 \mathrm{~W} \cdot \mathrm{m}^{-2} \cdot \mathrm{sr}^{-1} \cdot \mu \mathrm{m}^{-1}$ and $K_{2}$ is $1260.56 \mathrm{~K}$. For Landsat 8 TIRS $10, K_{1}$ is $774.89 \mathrm{~W} \cdot \mathrm{m}^{-2} \cdot \mathrm{sr}$ ${ }^{1} \cdot \mu \mathrm{m}^{-1}$ and $K_{2}$ is $1321.08 \mathrm{~K}$.

Finally, the mono-window algorithm was computed to obtain LST as follows [21]:

$$
T_{s}=\frac{a \times(1-C-D)+[b \times(1-C-D)+C+D] \times T_{b}-D \times T_{a}}{C}
$$

$$
\begin{gathered}
C=\tau \times \mathcal{E} \\
D=(1-\tau)[1+\tau(1-\varepsilon)]
\end{gathered}
$$

...where $T_{s}$ is the land surface temperature (LST) in K; $a$ is constant (-67.355351), $b$ is constant $(0.458606), \tau$ is the atmospheric transmission; $\varepsilon$ is the emissivity of the surface; and $T_{a}$ is the average atmospheric temperature in $\mathrm{K}$.

The term $\tau$ was calculated using the web-based atmospheric correction tool (available at http://atmcorr. gsfc.nasa.gov/) developed by Barisi et al. [42]. It should be mentioned that the tool cannot support the images before 2000 at present. Therefore, an alternative method proposed by Han et al. [43] has been introduced for the image of 1993 in this study (see the reference for detailed equations).

The average atmospheric temperature was calculated using Eq. (6) [44]:

$$
T_{a}=16.0110+0.92621 \times T_{0}
$$

...where $T_{0}$ is the near-surface air temperature in $\mathrm{K}$.
Term $\varepsilon$ was calculated using Eq. (7) [45-46]:

$$
\mathcal{E}=\left\{\begin{array}{cc}
0.920 & \text { NDVI }<0.2 \\
\varepsilon_{v} P_{v}+\varepsilon_{u}\left(1-P_{v}\right)+\mathrm{d} \varepsilon & 0.2 \leq N D V I \leq 0.5 \\
0.990 & N D V I>0.5 \\
0.995 & \text { Water }
\end{array}\right.
$$

...where $\varepsilon_{v}$ is the emissivity of vegetation and $\varepsilon_{u}$ is the emissivity of urban surface, the emissivity of vegetation is typically 0.99 , and the emissivity of urban surface is typically $0.92 ; P_{v}$ refers to the vegetation fraction; $d \varepsilon$ includes the geographical distribution of the natural surface; the emissivity of water is set as 0.995 .

The term $P_{v}$ was calculated using Eq. (8) [47]:

$$
P_{v}=\left[\frac{N D V I-N D V I_{\min }}{N D V I_{\max }-N D V I_{\min }}\right]^{2}
$$

$\ldots$ where $N D V I_{\max }=0.5, N D V I_{\min }=0.2$.

The term $d \varepsilon$ was calculated using Eq. (9) [48]:

$$
d \varepsilon=\left(1-\varepsilon_{u}\right)\left(1-P_{v}\right) F \varepsilon_{v}
$$

...where $F$ is the shape factor, whose mean value is 0.55 , assuming different geographical distribution.

\section{Relative Land Surface Temperature Index}

Because the acquisition date and meteorological conditions are not exactly the same for the four remotesensing images, the relative land surface temperature (RLST) (Eq. (10)) was used to compare the patterns of LST for the different years. The RLST is the LST difference between each of the LULC classes and the entire study area.

$$
R L S T_{\mathrm{i}}=L S T_{\mathrm{i}}-L S T_{\text {mean }}
$$

...where $R L S T_{i}$ is relative land surface temperature of land cover type $i$ in ${ }^{\circ} \mathrm{C}$; $i$ refers to land cover types, $L S T_{i}$ is the LST of this land cover type in ${ }^{\circ} \mathrm{C}$; and $L S T_{\text {mean }}$ is mean LST of the whole study area in ${ }^{\circ} \mathrm{C}$. If $R L S T>0$, then land cover type $i$ generates a positive contribution to NWDA's thermal environment (i.e., contributes to warming). If $R L S T_{i}<0$, then land cover type $i$ produces a negative contribution to the thermal environment (i.e., contributes to cooling).

\section{Quantifying Urban Expansion}

The study area was divided into four directions that were north, east, south, and west of the administrative center of Fuzhou city $\left(26^{\circ} 4^{\prime} 4^{\prime \prime \prime} \mathrm{N}, 119^{\circ} 17^{\prime} 24^{\prime \prime \prime} \mathrm{E}\right)$ in order 
to investigate the spatiotemporal distribution differences of urban sprawl. The extents and changes of built-up land area in each of these directions were characterized using the following indices (Eq. (11)-(12)).

$$
\begin{gathered}
A I=\frac{B_{b}-B_{\mathrm{a}}}{T} \\
A G R=\left[\left(\frac{B_{b}}{B_{a}}\right)^{\frac{1}{T}}-1\right] \times 100 \%
\end{gathered}
$$

...where $B_{a}$ and $B_{b}$ are the area of the built-up land at times $a$ and $b$, respectively; $T$ is the interval between $a$ and $b$.

A landscape index was proposed by Liu et al. [37] to distinguish the three urban growth types using Eq. (13).

$$
L E I=100 \times \frac{A_{o}}{A_{o}+A_{v}}
$$

...where $L E I$ is the landscape expansion index for a newly grown patch, $A_{0}$ is the intersection between the buffer zone (the buffer distance is set equal to $1 \mathrm{~m}$ ), and the occupied category, and $A_{v}$ is the intersection between the buffer zone and the vacant category. Urban growth type is determined as infilling when $50<L E I \leq 100$, edge-expansion when $0<L E I \leq 50$, and outlying when $L E I=0$.

\section{Spatial Autocorrelation Analysis}

Spatial autocorrelation indicates that the values of a variable at one location are correlated with the values of the same variable at its neighboring locations. Moran's I index was calculated using Eq. (14). The global spatial autocorrelation was implemented in the free software program GeoDa [49].

$$
\text { Moran's } I=\frac{n \sum_{i=1}^{n} \sum_{j=1}^{n} w_{i j}\left(x_{i}-\bar{x}\right)\left(x_{j}-\bar{x}\right)}{\sum_{i=1}^{n} \sum_{j=1}^{n} w_{i j} \sum_{i=1}^{n}\left(x_{i}-\bar{x}\right)^{2}}
$$

...where $n$ is the total number of observations; $x_{i}$ represents LST change at a particular location and $x_{j}$ indicates LST change at another location; $\bar{x}$ is the average LST change; and $w_{i j}$ is a measure of the spatial weights of data sites $i$ and $j$ at a given time. Moran's $I$ index ranges from -1.0 to 1.0. A positive value implies a positive autocorrelation, a negative value indicates a negative autocorrelation, and 0 indicates no spatial dependency. To compare two indices from different datum we used Moran's I and Z-score. The larger the
$Z$-score, the stronger spatial autocorrelation presents. In general, if the Z-score is larger than 2.58 or less than -2.58 , it is significant at the 0.01 level.

\section{Computation of Biophysical Indices}

The NDVI, NDMI, and NDISI were used to characterize the LULC types in the study area and to quantitatively examine the relationship between the LST and biophysical factors.

The normalized difference vegetation index (NDVI) (Eq.(15)) was generally used to express the density of vegetation.

$$
N D V I=\frac{\rho(N I R)-\rho(\text { Red })}{\rho(N I R)+\rho(\text { Red })}
$$

...where $\rho$ (NIR), and $\rho$ (Red) are reflectance of nearinfrared and red band, respectively.

The normalized difference moisture index (NDMI) (Eq.(16)) was used to measure wetness status as proposed by Gao [50].

$$
N D M I=\frac{\rho(N I R)-\rho(S W I R 1)}{\rho(N I R)+\rho(S W I R 1)}
$$

...where $\rho(\mathrm{NIR})$ and $\rho\left(S W I R_{\nu}\right)$ are reflectance of nearinfrared and shortwave infrared 1 band, respectively.

The normalized difference impervious surface index (NDISI) proposed by Xu (Eqs. (17)-(18)) [33] was used to enhance impervious surfaces and to suppress other land covers such as water, soil, and sand [51].

\begin{tabular}{|c|c|c|c|c|c|}
\hline \multirow{2}{*}{ LULC } & \multicolumn{4}{|c|}{ Area $\left(\mathrm{km}^{2}\right)$} & \multirow{2}{*}{$\begin{array}{c}\begin{array}{c}\text { Area of } \\
\text { Variation } \\
\left(\mathrm{km}^{2}\right)\end{array} \\
1993-2013\end{array}$} \\
\hline & 1993 & 2000 & 2008 & 2013 & \\
\hline Water & 196.29 & 178.82 & 168.27 & 166.90 & -29.39 \\
\hline Forest/Grass & 803.06 & 809.58 & 749.37 & 700.08 & -102.98 \\
\hline Cropland & 389.79 & 378.39 & 344.30 & 322.54 & -67.25 \\
\hline $\begin{array}{l}\text { Built-up } \\
\text { land }\end{array}$ & 175.14 & 193.68 & 306.50 & 380.34 & 205.20 \\
\hline Wetland & 37.00 & 35.30 & 31.91 & 30.36 & -6.64 \\
\hline Bare land & 3.10 & 8.61 & 4.03 & 4.16 & 1.06 \\
\hline
\end{tabular}

$N D I S I=\frac{\rho(T I R)-[\rho(M N D W I)+\rho(N I R)+\rho(S W I R 1)] / 3}{\rho(T I R)+[\rho(M N D W I)+\rho(N I R)+\rho(S W I R 1)] / 3}$

$$
M N D W I=\frac{\rho(\text { Green })-\rho(\text { SWIR } 1)}{\rho(\text { Green })+\rho(\text { SWIR } 1)}
$$

Table 3. Area statistics of different LULCs from 1993 to 2013. 


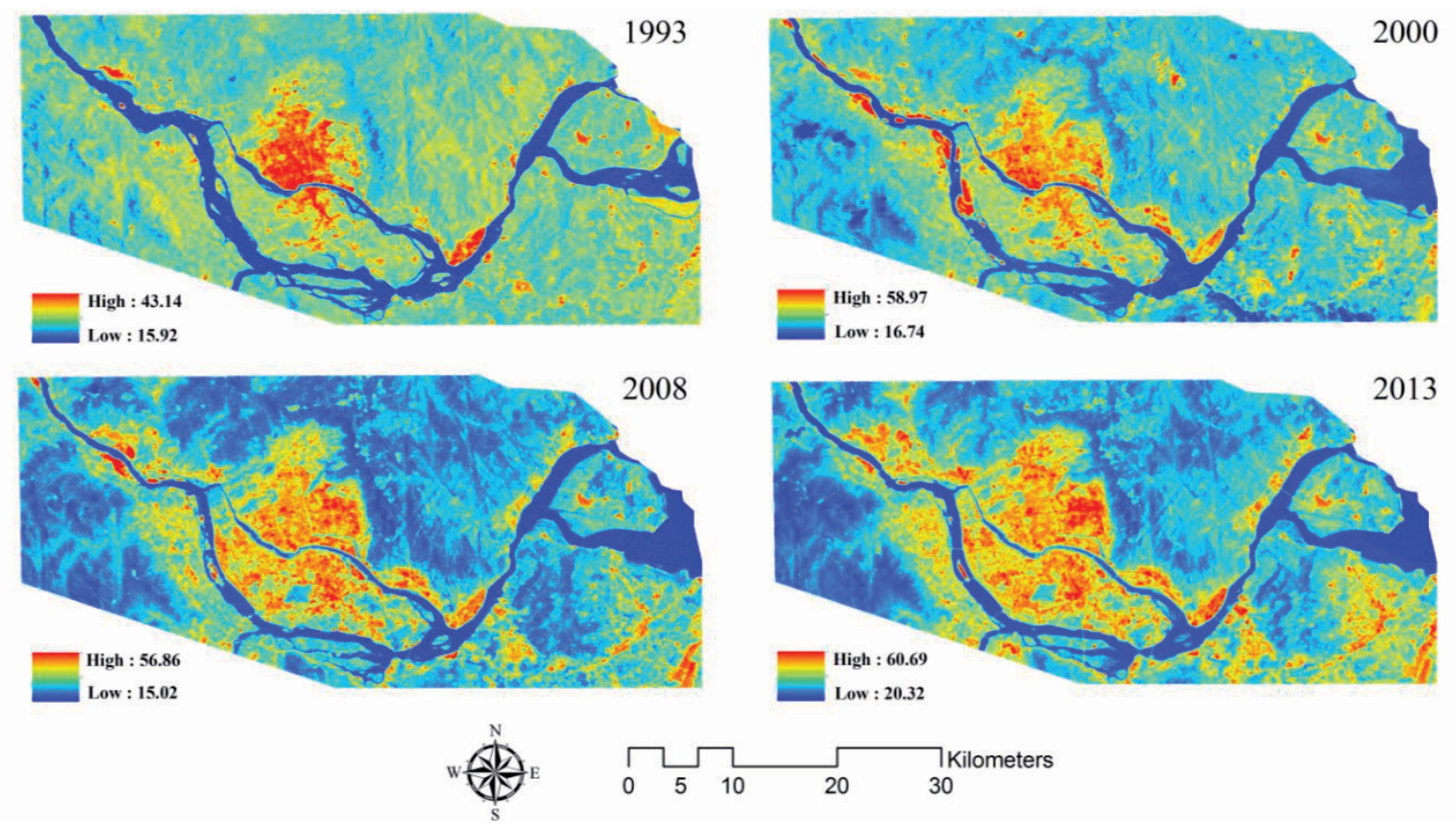

Fig. 3. LST maps of the study area from 1993 to 2013.

...where $\rho(T I R), \rho(N I R), \rho\left(S W I R_{\nu}\right)$, and $\rho($ Green $)$ are reflectance of thermal, near-infrared, shortwave infrared 1 , and green band, respectively; and MNDWI is the modified normalized difference water index. All input parameters in Eq. (12) were stretched to $[0,255]$ for Landsat TM and $[0,65535]$ for Landsat OLI/TIRS.

\section{Statistical Analysis}

Zonal analysis was used to calculate the mean LST at each $1 \%$ of built-up land, forest/grass, water, and cropland areas from 0 to $100 \%$. At each 0.1 increment of NDVI, NDMI, and NDISI, the mean LSTs were obtained from all corresponding values. Pearson's correlation coefficients were conducted to examine the strength of the relationship between LST and NDVI, NDMI and NDISI. Ridge regression analysis was used to further develop models to quantify the relationship between LST and biophysical composition variables, which could reduce and remove the multicollineartiy problem between explanatory variables [52].

\section{Results}

\section{LULC and Thermal Environment Dynamics}

Fig. 2 and Table 3 show the LULC spatiotemporal changes in the NWDA from 1993 to 2013. There was an obvious increase in the built-up land area, whereas the forest/grass and cropland areas declined. Remarkably, the area of wetland was reduced by $17.95 \%$ (from $37.00 \mathrm{~km}^{2}$ to $30.36 \mathrm{~km}^{2}$ ). Overall, the major LULC changes occurred along both sides of the Minjiang River, and the main change driver was the immense diffusion of built-up areas across the city center, spreading into suburban cropland regions and surrounding wetlands due to urbanization.

As shown in Fig. 3, LST in the study area during different years presents different spatial patterns. In 1993, the higher values of LST (as shown in red and orange in Fig. 3) were assembled around the administrative center zone and formed a monocentric pattern, which appeared as a small island surrounded by low LST regions (as shown in blue in Fig. 3). However, there was a trend for a higher value to spread outward from the center to peripheral areas, developing a polycentric pattern in 2013. The high LST zones were mainly observed in the center of Fuzhou city, where high-density commercial and residential areas were constructed; the low LST zones were mainly observed in areas of extensive forest and river.

The LST pattern is strongly correlated with the LULC distribution. Table 4 shows the statistics of the LST for the different LULC classes across the study period. The lowest values of LST were in the water areas, followed by the forest/grass, wetland and cropland

Table 4. Statistical table of LSTs in different land use/land cover classes $\left({ }^{\circ} \mathrm{C}\right)$.

\begin{tabular}{|l|l|c|c|c|c|c|c|}
\hline & Water & $\begin{array}{c}\text { Forest/ } \\
\text { Grass }\end{array}$ & $\begin{array}{c}\text { Crop- } \\
\text { land }\end{array}$ & $\begin{array}{c}\text { Built- } \\
\text { up land }\end{array}$ & $\begin{array}{c}\text { Wet- } \\
\text { land }\end{array}$ & $\begin{array}{c}\text { Bare } \\
\text { land }\end{array}$ & Mean \\
\hline 1993 & 20.22 & 25.22 & 25.87 & 30.63 & 23.54 & 29.06 & 25.76 \\
\hline 2000 & 21.88 & 28.21 & 31.29 & 39.10 & 30.02 & 45.39 & 32.65 \\
\hline 2008 & 24.52 & 27.27 & 31.53 & 38.83 & 31.13 & 40.64 & 32.32 \\
\hline 2013 & 26.59 & 30.61 & 36.44 & 42.91 & 34.63 & 42.63 & 35.64 \\
\hline
\end{tabular}




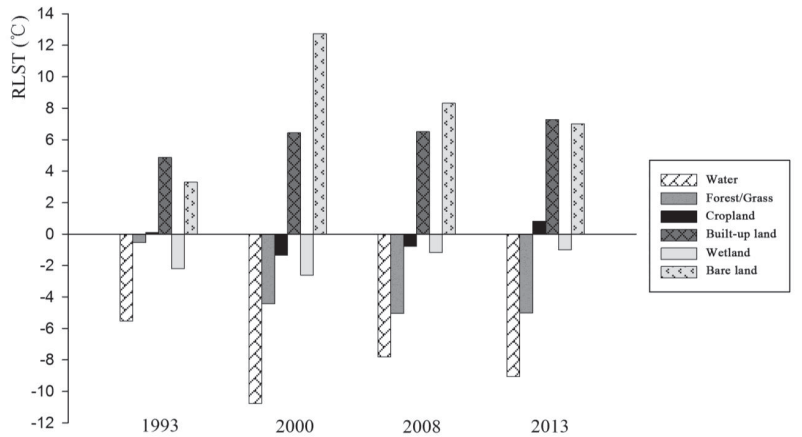

Fig. 4. RLST for different land use/land cover classes from 1993 to 2013 .

areas, and the built-up and bare land areas exhibited the highest values. As shown in Fig. 4, the contribution of different LULC types to the thermal environment of the NWDA, which was quantified by the RLST values, also varied. The built-up and bare land areas produced a positive contribution to the thermal environment of the whole region, while the water, forest/grass and wetland areas generated a negative contribution. The cropland area contributed negatively to the regional thermal environment in 2000 and 2008, but had an opposite result in 1993 and 2013. It is important to note that the mean RLSTs of wetland were $-2.22^{\circ} \mathrm{C},-2.63^{\circ} \mathrm{C},-1.19^{\circ} \mathrm{C}$, and $-1.01^{\circ} \mathrm{C}$ for the years $1993,2000,2008$, and 2013, respectively. These RLST values exhibited an increasing trend, indicating that the cooling effect of wetland was reduced.

\section{Urban Expansion Analysis}

The measurement of urban sprawl based on the speed and magnitude of built-up land for the NWDA was calculated (Table 5). As shown in the polar diagrams (Fig. 5), the spatial change of built-up land varied significantly in four directions over different periods. In the period 1993-2000, the AI and AGR of built-up land area were $2.65 \mathrm{~km}^{2} / \mathrm{a}$ and $1.45 \%$, respectively, which was much less than $10.26 \mathrm{~km}^{2} / \mathrm{a}$ and $3.95 \%$, respectively, of 1993-2013. The urban growth basically existed in the north direction, while other directions had low values of $\mathrm{AI}$ and AGR, indicating that it was a slow development period. In the period 2000-2008, the sprawl of builtup land occurred more quickly, most of the changes occurred in the east, south, and west sides of the study area; and the AGR of this stage peaked at $11.43 \%$. In 2008-2013, built-up land area maintained steady growth;

Table 5. Statistical table of built-up land in the different periods.

\begin{tabular}{|c|c|c|c|c|}
\hline & $1993-2000$ & $2000-2008$ & $2008-2013$ & $1993-2013$ \\
\hline AI $\left(\mathrm{km}^{2} / \mathrm{a}\right)$ & 2.65 & 14.10 & 14.77 & 10.26 \\
\hline AGR $(\%)$ & 1.45 & 5.91 & 4.41 & 3.95 \\
\hline
\end{tabular}
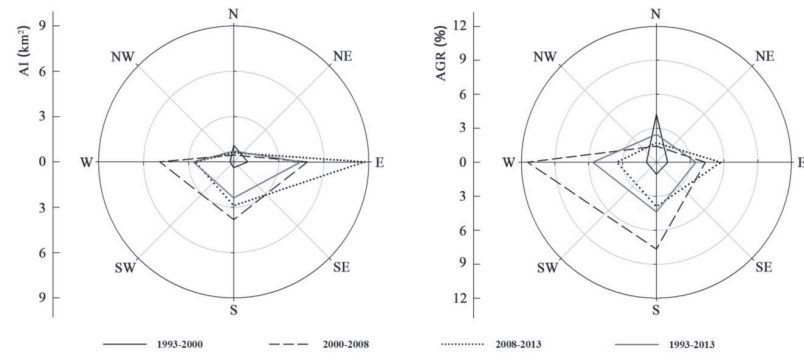

Fig. 5. Annual increase (AI) and annual growth rate (AGR) of built-up land in the different periods.

the east was the main expansive direction, while there were relatively small increases in the south and west. In summary, urban sprawl was initially observed toward the north, and later the western, southern, and eastern regions began to develop rapidly, showing a slow-rapidsteady and increasing urbanization process. Notably, the sprawl of the city northwards was relatively limited because of being blocked by the mountainous terrain.

Based on the LEI values, three urban growth types (infilling, edge-expansion, and outlying) were explored (Table 6). As illustrated, the edge-expansion area occupied $61.01 \%, 69.75 \%$, and $68.41 \%$ of the newly developed built-up land, while the number of patches accounted for $51.12 \%, 40.14 \%$, and $37.20 \%$ in 1993-2000, 2000-2008, and 2008-2013, respectively. Therefore, large-scale edge-expansion was the primary growth type in the NWDA throughout the study period. The proportion of infilling growth area decreased gradually for the three periods. In contrast, the outlying growth had an increase trend. Regarding the LST in the different urban growth types, infilling had the highest mean LST, followed by edge-expansion; and outlying had the lowest mean LST (Table 6) in the three different periods. This exhibited a broad trend in LST differences among the three types of urban growth patterns.

\section{Spatial Autocorrelation and Linear Regression Analysis}

To quantitatively measure the scaling effect of the spatial dependency of LST, the values of Moran's $I$ and Z-score were calculated at $300 \mathrm{~m}, 600 \mathrm{~m}, 900 \mathrm{~m}$, $1200 \mathrm{~m}$, and $1500 \mathrm{~m}$ grid cell sizes in 2013 (Table 7). Table 7 showed that, as the grid cell sizes increased, the minimum values of LST increased and the maximum values decreased. The shrinking difference between the highest and lowest values coincided with the declining mean LST and standard deviation. The values of Global Moran's I were greater than 0 , which confirmed that the LST is positively spatially autocorrelated. The Z-scores of Moran's I were much larger than $2.58 \quad(p<0.01)$, indicating that LST had a significant spatial clustering characteristic in the NWDA. However, when grid cell size increased, the Z-scores dropped from 229.41 to 37.22 , which demonstrated that the spatial dependency 
Table 6. Statistical table of three urban growth types in the different periods.

\begin{tabular}{|c|c|c|c|c|c|c|c|c|c|}
\hline \multirow{2}{*}{ Urban Growth Types } & \multicolumn{3}{|c|}{$1993-2000$} & \multicolumn{3}{c|}{$2000-2008$} & \multicolumn{3}{c|}{$2008-2013$} \\
\cline { 2 - 11 } & $\begin{array}{c}\text { Area } \\
(\%)\end{array}$ & $\begin{array}{c}\text { Number of } \\
\text { Patches }(\%)\end{array}$ & $\begin{array}{c}\text { LST } \\
\left({ }^{\circ} \mathrm{C}\right)\end{array}$ & $\begin{array}{c}\text { Area } \\
(\%)\end{array}$ & $\begin{array}{c}\text { Number of } \\
\text { Patches }(\%)\end{array}$ & $\begin{array}{c}\text { LST } \\
\left({ }^{\circ} \mathrm{C}\right)\end{array}$ & $\begin{array}{c}\text { Area } \\
(\%)\end{array}$ & $\begin{array}{c}\text { Number of } \\
\text { Patches }(\%)\end{array}$ & $\begin{array}{c}\text { LST } \\
\left({ }^{\circ} \mathrm{C}\right)\end{array}$ \\
\hline Infilling & 29.51 & 27.86 & 37.44 & 21.78 & 30.76 & 37.29 & 17.20 & 24.72 & 41.80 \\
\hline Edge-expansion & 61.01 & 51.12 & 35.22 & 69.75 & 40.14 & 34.95 & 68.41 & 37.20 & 38.57 \\
\hline Outlying & 9.48 & 21.02 & 34.69 & 8.47 & 29.10 & 33.02 & 14.39 & 38.08 & 33.88 \\
\hline
\end{tabular}

Table 7. Changes of LST statistical variables at five scales in study area (2013).

\begin{tabular}{|c|c|c|c|c|c|}
\hline Grid & $300 \mathrm{~m} \times 300 \mathrm{~m}$ & $600 \mathrm{~m} \times 600 \mathrm{~m}$ & $900 \mathrm{~m} \times 900 \mathrm{~m}$ & $1200 \mathrm{~m} \times 1200 \mathrm{~m}$ & $1500 \mathrm{~m} \times 1500 \mathrm{~m}$ \\
\hline Min $\left({ }^{\circ} \mathrm{C}\right)$ & 22.74 & 22.82 & 22.82 & 23.52 & 23.78 \\
\hline $\operatorname{Max}\left({ }^{\circ} \mathrm{C}\right)$ & 58.14 & 52.98 & 50.35 & 50.31 & 50.27 \\
\hline Mean $\left({ }^{\circ} \mathrm{C}\right)$ & 34.35 & 34.32 & 34.29 & 34.27 & 34.26 \\
\hline Standard deviation $\left({ }^{\circ} \mathrm{C}\right)$ & 6.24 & 5.93 & 5.69 & 5.49 & 5.38 \\
\hline Moran's $I$ & 0.86 & 0.80 & 0.76 & 0.73 & 0.70 \\
\hline Z-score & 229.41 & 106.84 & 67.41 & 48.64 & 37.22 \\
\hline
\end{tabular}

of LST became weaker, and the spatial patterns of LST had an evident scale effect.

Given that LST varies with different LULC types, as demonstrated above, linear regression models were established to explore the relationship between LST and different LULC types at a $600 \mathrm{~m}$ scale (Fig. 6). The results showed that there was a significant positive correlation between LST and built-up land area; every
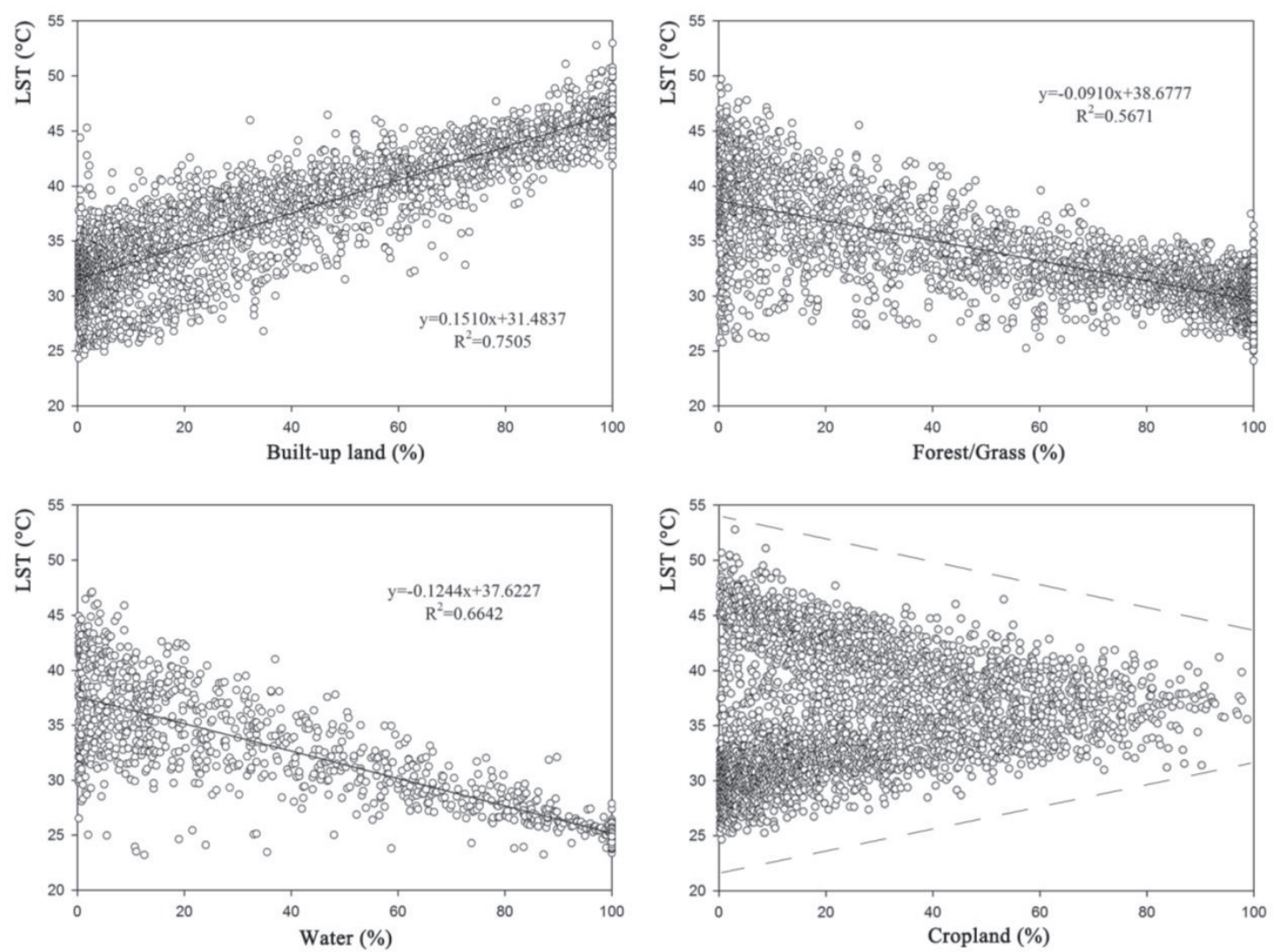

Fig. 6. Linear regression analysis between different LULC types and LST at a 600m scale in 2013 


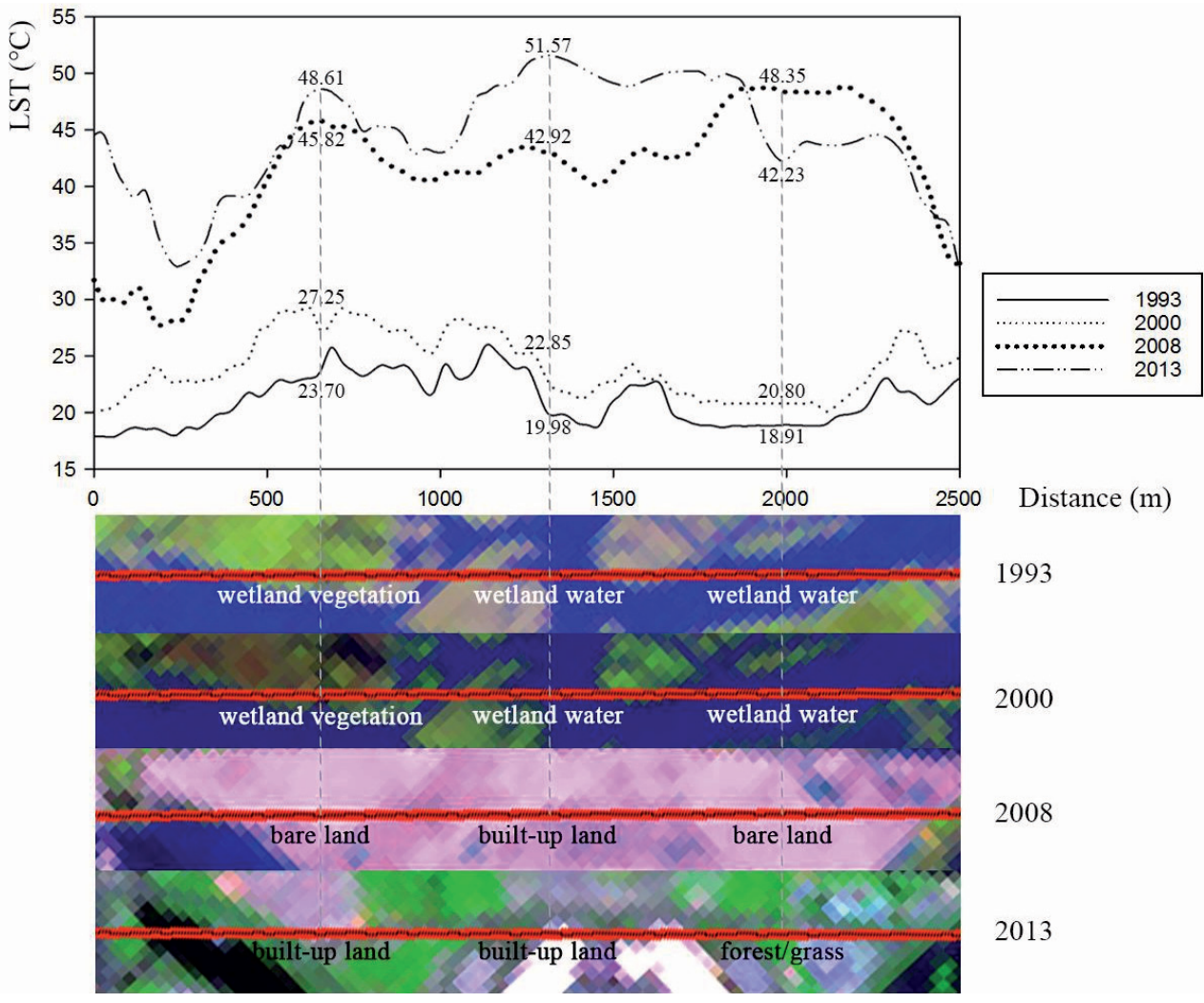

Fig. 7. Profile analysis map of Puxiazhou surface temperature disturbance.

increase of $10 \%$ in built-up land area will increase the LST by $1.51^{\circ} \mathrm{C}$. Meanwhile, there was a negative correlation between LST and forest/grass and water area, indicating that increasing the dominance of forest/grass and water areas could reduce the surface temperature. Remarkably, cropland did not show obvious warming or cooling effects, but the LST tended to be stable as the proportion of cropland increased.

\section{Modeling Wetland Surface Temperature Disturbance Characteristics}

\section{Spatial Profiles of LST Distribution}

Driven by urbanization, a sharp increase in builtup land area led to the loss of natural wetlands, and drastic thermal environment changes occurred inside the wetlands. The Puxiazhou wetland was selected as a typical research site because its surface temperature showed large variations under the influence of human activities and natural factors. The northwest-southeast (as shown in Fig. 1 as the red, bold line) profile maps of Puxiazhou were constructed to analyze the LST distribution of various LULC types in 1993, 2000, 2008, and 2013 (Fig. 7).

By comparing the LULC types in the four years, LULC changes that affect temperature fluctuation were observed. In 1993 and 2000, the distribution of the LULC profile was mainly wetland vegetation and wetland water with low and stable surface temperature. In 2008,
Puxiazhou was developed to include the Fuzhou Strait International Conference and Exhibition Center. Since then, large areas of natural wetland converted into builtup and bare land areas have resulted in wetland surface temperatures reaching $51.57^{\circ} \mathrm{C}$ in 2013 and exceeding $30^{\circ} \mathrm{C}$ in 1993 . On the whole, higher LSTs were usually found in impervious surfaces; otherwise, lower LSTs were generally located in vegetation and water areas.

\section{Correlation between LST and NDVI, NDMI, and NDISI}

The intensity of vegetation, moisture, and impervious surfaces were important indicators for assessing the thermal environment. Different indices, namely NDVI, NDMI, and NDISI, were used to examine the correlation between LST and various biophysical parameters. In total, 1440 random points inside wetlands were chosen; then, values of NDVI, NDMI, and NDISI were extracted from each random point. Furthermore, the mean LSTs at 0.1 increments from the minimum and maximum NDVI, NDMI, and NDISI were evaluated to analyze the relationship between LST and NDVI (Fig. 8), between LST and NDMI (Fig. 9), and between LST and NDISI (Fig. 10).

LST had an inverse relationship with NDVI $(p<0.01)$, indicating that LST decreased as NDVI increased. This observation is crucial in the sense that increasing vegetation density is an effective solution to mitigate wetland surface high temperature. 

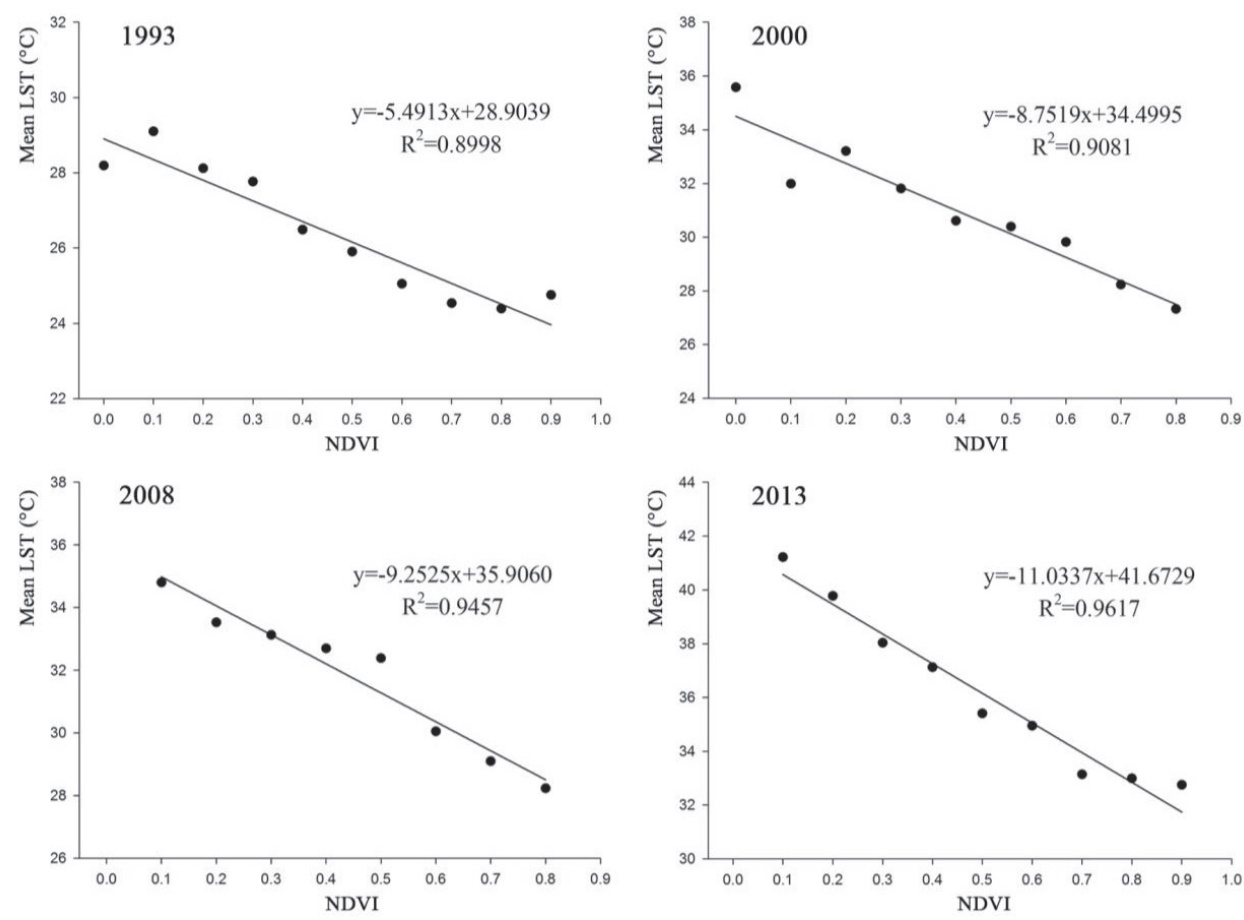

Fig. 8. Relationship between LST and NDVI.

LST was negatively correlated with NDMI $(p<0.01)$. This highlights a distinct conclusion about the vital role of moisture in mitigating thermal conditions. The higher values of NDMI were water, paddy field, and vegetation areas with abundant liquid water followed by dry land and vegetation areas with scarce liquid water; impervious surface areas had the lowest values of NDMI. However, the relationship between LST and NDMI was not linear but instead exponential, and the decreasing tendency slowed as NDMI increased.

In contrast, the relationship between LST and NDISI was significantly positive $(p<0.01)$. This implies that as NDISI increases, LST also increases. In addition, the regression slopes increased gradually, indicating that
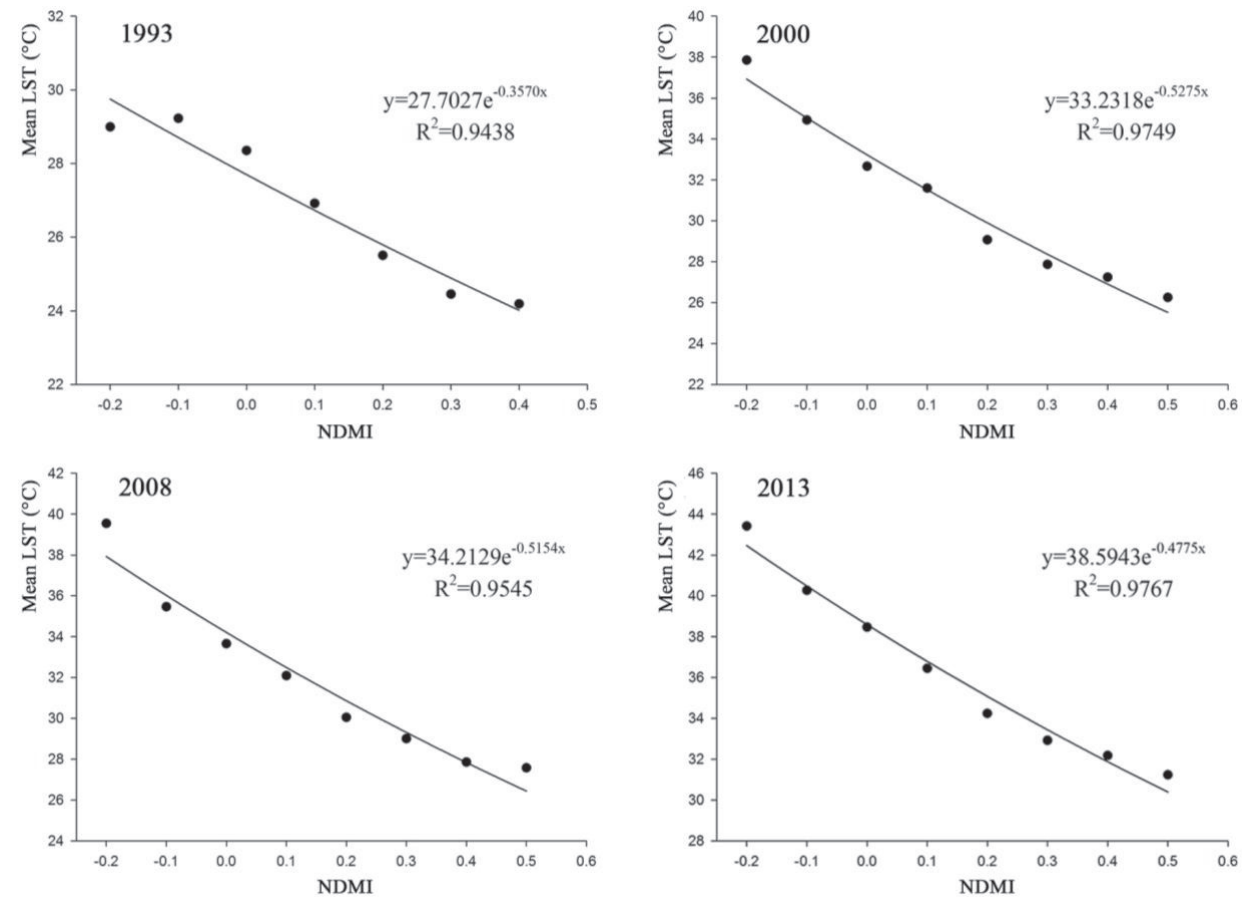

Fig. 9. Relationship between LST and NDMI. 

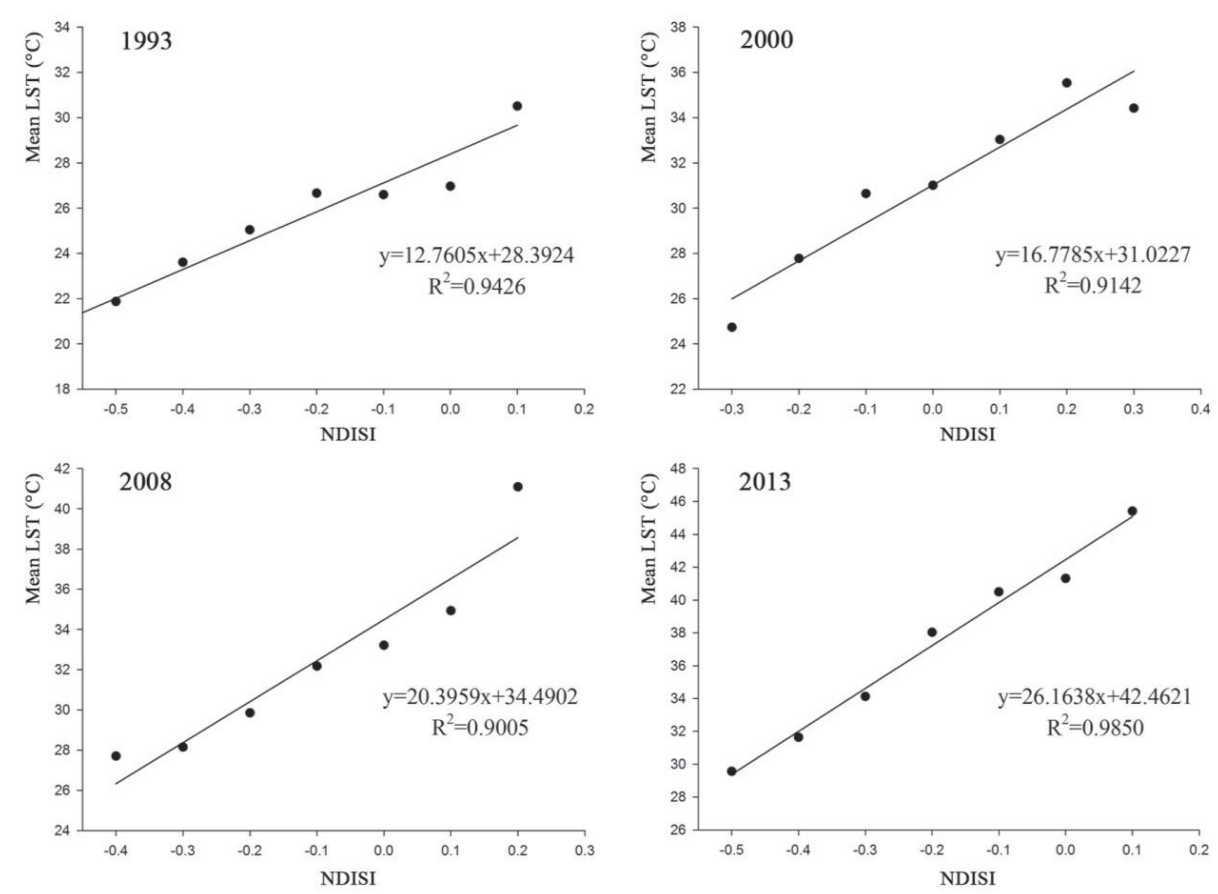

Fig. 10. Relationship between LST and NDISI.

every increase of 0.1 in NDISI would increase mean LST by $1.28^{\circ} \mathrm{C}$ in $1993,1.68^{\circ} \mathrm{C}$ in $2000,2.04^{\circ} \mathrm{C}$ in 2008 , and $2.62^{\circ} \mathrm{C}$ in 2013 . Results suggested that impervious surfaces played an increasingly primary role in the wetland thermal environment.

To further quantitatively explore how three biophysical parameters performed their combining effects on wetland surface temperature, ridge regression models between LST and NDVI, NDMI, and NDISI were developed as follows:

- 1993: LST=29.51-1.55NDVI-7.87NDMI+5.95NDISI $R^{2}=0.7277$

- 2000: LST=33.05-0.93NDVI-9.71NDMI+7.47NDISI $R^{2}=0.6656$

- 2008: LST=34.18-0.72NDVI-8.02NDMI+10.04NDISI $R^{2}=0.6374$

- 2013: LST=41.96-0.57NDVI-7.62NDMI+20.99NDISI $R^{2}=0.7827$

The regression coefficients $\left(R^{2}\right)$ indicate that all of the biophysical variables played important roles in wetland thermal conditions and thus can be used as predictor variables $(p<0.01)$. Nevertheless, the three indices worked differently, as indicated by their coefficients. The negative coefficients of NDVI and NDMI, and positive coefficients of NDISI implied that within the wetlands, vegetation and moisture contributed to a decrease in LST while the impervious surface strengthened LST. In light of the values of the coefficients, the NDVI coefficients were far below that of NDMI and NDISI, which suggested that moisture and impervious surface had greater impact on LST than vegetation. In 1993 and 2000, NDMI was the dominant factor in determining LST, followed by NDISI. In
2008 and 2013, the coefficients of NDISI had higher values than NDMI. As seen in 1993-2013, the NDISI coefficients increased from 5.95 to 20.99. This can be explained by the LULC changes during this period. Impervious surface areas, indicated by low NDVI, low NDMI, and high NDISI, increased and occupied a large proportion of other high NDVI, high NDMI, and low NDISI land use types such as water and vegetation.

\section{Discussion}

Despite differences between LST and air temperature, air temperature has been shown to be highly correlated with LST $[1,5]$. The meteorological site data were used to verify the LST inversion accuracy due to the lack of actual measurements, which showed that the average air temperatures of Fuzhou City were $25.0^{\circ} \mathrm{C}, 31.4^{\circ} \mathrm{C}, 31.4^{\circ} \mathrm{C}$, and $32.0^{\circ} \mathrm{C}$ on 26 June 1993,29 June 2000, 5 July 2008, and 4 August 2013, respectively. The LSTs retrieved by the mono-window algorithm were $25.76^{\circ} \mathrm{C}, 32.65^{\circ} \mathrm{C}, 32.32^{\circ} \mathrm{C}$, and $35.64^{\circ} \mathrm{C}$ on 26 June 1993, 29 June 2000, 5 July 2008, and 4 August 2013, respectively (Table 4). Accordingly, the errors were in the acceptable range, thereby manifesting that the LST inversion results were reasonable and receivable.

\section{Effects of Different Land Use/Land Cover Types}

This study illustrated that different LULC types have different effects on the thermal environment (Table 4 and Fig. 6). The built-up and bare land areas 
strengthened the thermal environment magnitude; and the greater the percentage of built-up land, the higher the regional temperature. This is due to high-density building areas impeding heat removal by wind, further elevating LST [38]. Nevertheless, the water, forest/grass, and wetland areas contributed to mitigating the regional high temperature, and the cooling effects increased as the proportion of forest/grass and water areas increased. Similar findings have been shown in previous studies [53-54]. The results reveal that raising the percentage of forest/grass and water areas and decreasing built-up land density are valid high-temperature mitigation solutions. However, in contrast to existing studies in which cropland areas have been found to negatively contribute to $\operatorname{LST}[5,27,55]$, this land cover type showed an indistinctive cooling effect or even an adverse impact on the thermal environment of the NWDA. It is consistent with the observation from Fig. 6 that cropland exhibited an insignificant negative or positive contribution to the thermal environment, but the LST tends to be stable as the proportion of cropland increases. In general, cropland is composed of relatively sparse vegetation and exposed bare soil, which is less effective in mitigating the urban warming effect than forest/grass [53]. On the other hand, urban sprawl not only transforms a mass of croplands into built-up land areas but also enhances the fragmentation of croplands, leading to a weaker cooling effect. Furthermore, the accelerated pace of urbanization caused an increase in LST in cropland areas close to the adjoining built-up region with high temperatures. In addition, the thermal characteristics of cropland are also speculated to vary with season, soil moisture, and vegetation growth conditions. Thus more research is needed on the effect of cropland on the thermal environment [54]. It should be noted that wetland, which has a general cooling effect on the environment, demonstrated a relatively high RLST value of $-1.01^{\circ} \mathrm{C}$ in 2013, which was almost equal to the mean LST of the NWDA. This mainly resulted from the loss of natural wetland areas, leading to an obvious increase in the average LST of wetlands, which masks the positive cooling effect of wetlands from the perspective of the entire region.

These results can offer meaningful action points for urban planning that can mitigate the effect of high temperature. First, the cooling effects of forest/grass and water are particularly effective in elevated temperature zones. Hence, it is necessary to add forest/grass and water areas to a high density of buildings, even though there was a strong demand for land development due to rapid urbanization. Second, to maintain the stable temperature of the cropland, it is necessary to optimize the spatial arrangements by clustering croplands and keeping these away from high-temperature regions. Finally, the cooling effect of wetland is significant in an urban environment, and a better understanding of wetland surface temperature disturbance characteristics is crucial to promoting its specific ecosystem services.

\section{Implications for Urban Planning}

Since the late 1990s, the State Council of China has released a series of policies to support the developments of west-strait economic zones around the city center and along the Minjiang River, which stimulated the establishments of intensive industrial parks, settlements, college parks, commercial facilities, airport, and expressway systems liking the city proper with suburban and rural areas [56-57]. Therefore, the study area has experienced ongoing and accelerated urbanization. Urbanization is a powerful force that drives land use/land cover changes and elevated land surface temperatures. It is meaningful to understand the mechanisms and dynamics of the thermal environment brought on by fast urbanization.

Above all, it is thought that the area of built-up land could be regarded as the urbanized area on the LULC maps to analyze the urban sprawl of NWDA. Built-up land expanded rapidly over two decades, and the percentage of built-up land in the total area in 2013 (23.71\%) was approximately double the percentage in 1993 (10.91\%). Most of the built-up lands is converted at the cost of croplands, forests, and natural wetlands; and such a phenomenon has also been observed in many cities worldwide. For example, Feng et al. [58] stated that in Beijing city the cost of built-up area sprawl was the decrease of farmland area. Then Mushore et al. [38] found that built-up areas increase in coverage at the expense of green spaces and wetlands in Harare. The increases in temperature due to LULC changes are also consistent with previous studies [59-60]. Urban development greatly depends on government policies. According to the Fuzhou master plan (1995-2010 and 2011-2020), the spatial development strategy was southward and eastward sprawl. In the same time period, the directions mentioned above have been observed (Fig. 5). The relative percentage areas of the three urban growth types provide detailed information about the dominance of changing urban expansion modes over time (Table 6). Urban growth is always accompanied by diffusion and coalescence phases, but urban growth in the NWDA was mainly in the process of sprawl and diffusion because there was still abundant available land for urban development.

In addition, exploring the responses of temperature to urban growth patterns provided essential feedback to policy makers in developing urban planning strategies. The study showed that different urban growth types had diverse effects on the regional thermal environment. The infilling type had the highest mean LST, followed by the edge-expansion type, and the outlying type had the lowest mean LST. There are several reasons for this pattern. Initially, the infilling patches are enclosed by high LST land cover classes, such as construction land areas, which have a positive contribution to the infilling areas' LST by changing the humidification and evaporative status of surroundings [3]. Instead, the outlying patches are enclosed by low LST land 
cover classes, such as forest/grass and cropland areas, which reduce regional temperature. Second, the edgeexpansion areas are surrounded by high built-up land and other LULC classes, which results in temperatures higher than outlying areas and lower than infilling areas. Third, the outlying areas often have good planning policies that are accompanied by an appropriate proportion of ecological land like urban green space, water, and wetland areas [34]. This planning, coupled with a suitable LULC structure, can mitigate the high temperature of the region. Infill development has been promoted due to the potential benefits, such as the use of existing infrastructure and the advancement of walkable neighborhoods. However, infill development has also brought about many problems, such as urban high temperatures and crowded services [61-62]. Therefore, constructing new urban areas with suitable LULC structures in place of infilling types is an effective method to maintain thermal comfort.

\section{Implications for Wetland Protection and Management}

This study examined how the relationship between LST and wetland biophysical parameters could provide important insights into wetland protection and management. The results showed a negative correlation between LST and NDVI. Vegetation cools temperature mainly through shading and evapotranspiration processes, which absorbs heat energy and releases water vapor and thus reduces the temperature in the ambient air [8, 18, 63]. The positive correlation between LST and NDISI can be explained by the fact that impervious surfaces (such as buildings, rooftops, pavement covered by concrete, asphalt, and brick) have high solar radiation absorptivity, low water storage capacity, and latent heat transfer, which lowers the humidity of the ground $[18,38]$. According to $\mathrm{Lu}$ et al. [64], the reduction of humidity causes slow transpiration and then promotes land surface temperature to rise readily. This is also the reason why NDMI has a positive influence on LST.

The ridge regression models were created with LST and NDVI, NDMI, and NDISI, which can be adopted to monitor and estimate the thermal environment of wetlands. According to the equations, the effects of vegetation, moisture, and impervious surfaces on wetland surface temperature were unequal. As has been proven in previous studies [7, 65], the LST increase in areas where ecological land has been converted to impervious surface is greater than the LST decrease in areas where green space is sprawling. In this study, the importance of NDVI was weaker than that of NDMI and NDISI in all regressions; NDISI became the dominant factor influencing LST over NDMI through the urbanization process. Excessive impervious surface exploitation inside the wetlands for farming, residential, and recreation purposes has undermined estuarine wetland ecosystem, which not only elevated the surface temperature but also impaired the function of wetlands in regulating regional thermal environments. Therefore, the development of impervious surfaces will face a severe challenge on potentiating the effect of high temperature.

To better improve the thermal condition of wetlands, wetland vegetation with high liquid water and wetland water areas should be increased, whereas impervious surfaces should be limited as much as possible. In addition, there is an urgent need to draw a red line in wetland conservation against further exploitation. With these changes, the improved regulatory function and ecological benefits of wetlands will be realized.

\section{Limitations and Potential Improvements}

The results of this study may be subject to several limitations. Foremost, the present study only focused on the LST at approximately 10:00 local time in summer, and the diurnal and seasonal variabilities were not analyzed. Nevertheless, Qiao et al. [5] found that the different LULC classes that contributed to the regional thermal environment varied diurnally and seasonally. Peng et al. [66] noted that the summer nighttime period was the pivotal temporal period for urban thermal environment management. Therefore, dynamic research regarding the connection between LST and corresponding land cover features need to be undertaken. Additional variables such as climatic conditions, landscape configuration [27], population density [6], height of buildings, and forested canyons [67], also warrant investigation. Furthermore, a few wetlands, such as Longxiangdao and Liushifenzhou, also suffer significant stress from urban development, similar to Puxiazhou. However, the absence of highresolution images hinders us from examining land cover and land surface temperature variations inside wetlands at fine spatial scales. Finally, models that can effectively predict wetland surface temperature distribution were proposed based on the ridge regression method (RRM) in this study, whereas much research $[55,68]$ has demonstrated that the partial least squares regression method (PLSRM) was efficient for identifying important indicators for determining LST. Hence a comparison between RRM and PLSRM can be performed to obtain better models for wetland thermal environment monitoring in further analysis.

\section{Conclusions}

The present study, based on remote sensing data, spatial analysis, and statistical methods, provides insights into the relationship between LST and LULC changes as well as the disturbance characteristics of wetland surface temperature in the NWDA under rapid urbanization during the 1993-2013 period. The findings suggest that the major LULC changes occurred along both sides of the Minjiang River, and the main change driver was the conversion of forest/grass and cropland 
areas to built-up land areas due to urbanization. The LST patterns were related to the distribution of LULC. In addition, urban growth types affected urban thermal environment differently; the infilling type exacerbated impact on local high temperature followed by edgeexpansion type, and outlying type relatively contributed to the mitigation of thermal effect. Moreover, the density of built-up land increases resulted in a rise in regional mean LST, and increasing the percentage of water and forest/grass areas helped to maximize their cooling effect on the peripheral region. Finally, the relationship between LST and NDVI, NDMI, and NDISI was examined inside wetlands by developing ridge regression models, which highlighted that the acceptance of measures to increase vegetation with high liquid water and limit impervious surface areas should be taken to alleviate the wetland surface higher temperature and protect wetland ecosystem. The obtained results are expected to provide beneficial guidance that will ultimately result in a comfortable living environment and effective wetland conservation within the process of China's new urbanization.

\section{Acknowledgements}

This study was financially supported by the Fujian Province Youth Social Science Project (No. FJ2016C033). Many thanks to the United States Geographical Survey (USGS) and China Meteorological Data Service Center (CMDC) for providing the freely accessible data. Thanks also to the anonymous reviewers for their helpful comments on this manuscript.

\section{Conflict of Interest}

The authors declare no conflict of interest.

\section{References}

1. SUN R., CHEN A., CHEN L., LÜ Y. Cooling effects of wetlands in an urban region: The case of Beijing. Ecological Indicators, 20 (9), 57, 2012.

2. DU H., SONG X., JIANG H., KAN Z., WANG Z., CAI Y. Research on the cooling island effects of water body: A case study of Shanghai, China. Ecological Indicators, 67, 31, 2016.

3. XU H., SHI T., WANG M., FANG C., LIN Z. Predicting effect of forthcoming population growth-induced impervious surface increase on regional thermal environment: Xiong'an New Area, North China. Building and Environment, 136, 98, 2018.

4. SINGH P., KIKON N., VERMA P. Impact of land use change and urbanization on urban heat island in Lucknow city, Central India. A remote sensing based estimate. Sustainable Cities and Society, 32, 100, 2017.

5. QIAO Z., TIAN G., XIAO L. Diurnal and seasonal impacts of urbanization on the urban thermal environment: A case study of Beijing using MODIS data. ISPRS Journal of Photogrammetry and Remote Sensing, 85 (2), 93, 2013.

6. ZHANG H., QI Z., YE X., CAI Y., MA W., CHEN M. Analysis of land use/land cover change, population shift, and their effects on spatiotemporal patterns of urban heat islands in metropolitan Shanghai, China. Applied Geography, 44 (4), 121, 2013.

7. SUN R., CHEN L. Effects of green space dynamics on urban heat islands: Mitigation and diversification. Ecosystem Services, 23, 38, 2017.

8. ZHANG B., XIE G., GAO J., YANG Y. The cooling effect of urban green spaces as a contribution to energy-saving and emission-reduction: A case study in Beijing, China. Building and Environment, 76 (76), 37, 2014.

9. CAO X., ONISHI A., CHEN J., IMURA H. Quantifying the cool island intensity of urban parks using ASTER and IKONOS data. Landscape and Urban Planning, 96 (4), 224, 2010.

10. MONDAL B., DOLUI G., PRAMANIK M., MAITY S., BISWAS S., PAL R. Urban expansion and wetland shrinkage estimation using a GIS-based model in the East Kolkata Wetland, India. Ecological Indicators, 83, 62, 2017.

11. SICA Y., QUINTANA R., RADELOFF V., GAVIERPIZARRO G. Wetland loss due to land use change in the Lower Paraná River Delta, Argentina. Science of the Total Environment, 568, 967, 2016.

12. ZHANG B., SHI Y., LIU J., XU J., XIE G. Economic values and dominant providers of key ecosystem services of wetlands in Beijing, China. Ecological Indicators, 77, 48, 2017.

13. CAI Y., ZHANG H., ZHENG P., PAN W. Quantifying the impact of land use/land cover changes on the urban heat island: A case study of the natural wetlands distribution area of Fuzhou city, China. Wetlands, 36 (2), 285, 2016.

14. WU W., ZHOU Y., TIAN B. Coastal wetlands facing climate change and anthropogenic activities: A remote sensing analysis and modelling application. Ocean \& Coastal Management, 138, 1, 2017.

15. MENG W., HE M., HU B., MO X., LI H., LIU B., WANG Z. Status of wetlands in China: A review of extent, degradation, issues and recommendations for improvement. Ocean \& Coastal Management, 146, 50, 2017.

16. TIAN H., LINDENMAYER D., WONG G., Mao Z., HUANG Y., XUE X. A methodological framework for coastal development assessment: A case study of Fujian Province, China. Science of the Total Environment, 615, 572, 2017.

17. DENG Y., WANG S., BAI X., TIAN Y., WU L., XIAO J., CHEN F., QIAN Q. Relationship among land surface temperature and LUCC, NDVI in typical karst area. Scientific Reports, 8 (1), 641, 2018.

18. DOS SANTOS A.R., De OLIVEIRA F.S., DA SILVA A.G., GLERIANI J.M., GONCALVES W., MOREIRA G.L., SILVA F.G., FIGUEIRA BRANCO E.R., MOURA M.M., DA SILVA R.G., JUVANHOL R.S., DE SOUZA K.B., SOARES RIBEIRO C.A.A., DE QUEIROZ V.T., COSTA A.V., LORENZON A.S., DOMINGUES G.F., MARCATTI G.E., DE CASTRO N.L.M., RESENDE R.T., GONZALES D.E., DE CASTRO N.L.M., RESENDE R.T., GONZALES D.E., DE ALMEIDA TELLES L.A., TEIXEIRA T.R., DOS SANTOS G.M.A.D.A., SANTOS MOTA P.H. Spatial and temporal distribution of urban heat islands. Science of the Total Environment, 605-606, 946, 2017. 
19. CHAUDHURI G., MISHRA N. Spatio-temporal dynamics of land cover and land surface temperature in GangesBrahmaputra delta: A comparative analysis between India and Bangladesh. Applied Geography, 68, 68, 2016.

20. WANG S., MA Q., DING H., LIANG H. Detection of urban expansion and land surface temperature change using multi-temporal landsat images. Resources, Conservation and Recycling, 128, 526, 2018.

21. QIN Z., ZHANG M., ARNON K., PEDRO B. Monowindow algorithm for retrieving land surface temperature from Lansat TM 6 data. Acta Geographica Sinica, 56 (4), 456, 2001.

22. VOOGT J., OKE T. Thermal remote sensing of urban climates. Remote Sensing of Environment, 86 (3), 370, 2003

23. WARD K., LAUF S., KLEINSCHMIT B., ENDLICHER W. Heat waves and urban heat islands in Europe: A review of relevant drivers. Science of the Total Environment, 569570, 527, 2016.

24. JAGANMOHAN M., KNAPP S., BUCHMANN C.M., SCHWARZ N. The bigger, the better? The influence of urban green space design on cooling effects for residential areas. Journal of Environmental Quality, 45 (1), 134, 2016.

25. XU H., LIN D., TANG F. The impact of impervious surface development on land surface temperature in a subtropical city: Xiamen, China. International Journal of Climatology, 33 (8), 1873, 2013.

26. ZHANG Y., ODEH I.O.A., HAN C. Bi-temporal characterization of land surface temperature in relation to impervious surface area, NDVI and NDBI, using a subpixel image analysis. International Journal of Applied Earth Observation and Geoinformation, 11 (4), 256, 2009.

27. PENG J., XIE P., LIU Y., MA J. Urban thermal environment dynamics and associated landscape pattern factors: A case study in the Beijing metropolitan region. Remote Sensing of Environment, 173, 145, 2016.

28. SONG J., DU S., FENG X., GUO L. The relationships between landscape compositions and land surface temperature: Quantifying their resolution sensitivity with spatial regression models. Landscape and Urban Planning, 123 (1), 145, 2014

29. WU H., YE L., SHI W., CLARKE K. Assessing the effects of land use spatial structure on urban heat islands using HJ-1B remote sensing imagery in Wuhan, China. International Journal of Applied Earth Observation and Geoinformation, 32 (1), 67, 2014

30. GUO G., WU Z., XIAO R., CHEN Y., LIU X., ZHANG X. Impacts of urban biophysical composition on land surface temperature in urban heat island clusters. Landscape and Urban Planning, 135, 1, 2015.

31. MALLICK J., SINGH C.K., SHASHTRI S., RAHMAN A., MUKHERJEE S. Land surface emissivity retrieval based on moisture index from LANDSAT TM satellite data over heterogeneous surfaces of Delhi city. International Journal of Applied Earth Observation and Geoinformation, 19 (10), 348, 2012

32. LI B., WANG H., QIN M., ZHANG P. Comparative study on the correlations between NDVI, NDMI and LST. Progress in Geography, 36 (5), 585, 2017.

33. XU H. Analysis of impervious surface and its impact on urban heat environment using the normalized difference impervious surface index (NDISI). Photogrammetric Engineering and Remote Sensing, 76 (5), 557, 2010.

34. TRAN D.X., PLA F., LATORRE-CARMONA P., MYINT S.W., CAETANO M., KIEU H.V. Characterizing the relationship between land use land cover change and land surface temperature. ISPRS Journal of Photogrammetry and Remote Sensing, 124, 119, 2017.

35. TU L., QIN Z., LI W., GENG J., YANG L., ZHAO S. ZHAN W., WANG F. Surface urban heat island effect and its relationship with urban expansion in Nanjing, China. Journal of Applied Remote Sensing, 10 (2), 026037, 2016.

36. LI X., ZHOU Y., ASRAR G.R., IMHOFF M., LI X. The surface urban heat island response to urban expansion: A panel analysis for the conterminous United States. Science of the Total Environment, 605-606, 426, 2017.

37. LIU X., LI X., CHEN Y., TAN Z., LI S., AI B. A new landscape index for quantifying urban expansion using multi-temporal remotely sensed data. Landscape Ecology, 25 (5), 671, 2010.

38. MUSHORE T.D., ODINDI J., DUBE T., MUTANGA O. Prediction of future urban surface temperatures using medium resolution satellite data in Harare metropolitan city, Zimbabwe. Building and Environment, 122, 397, 2017.

39. YU X., GUO X., WU Z. Land surface temperature retrieval from Landsat 8 TIRS - Comparison between radiative transfer equation-based method, split window algorithm and single channel method. Remote Sensing, 6 (10), 9829, 2014.

40. Landsat 7 science data users handbook. Washington, DC: Goddard Space Flight Center, NASA. Available online: http://landsathandbook.gsfc.nasa.gov/handbook.html (accessed on 2011).

41. Landsat 8 (L8) data users handbook. Washington, DC: Goddard Space Flight Center, NASA. Available online: http://landsathandbook.gsfc.nasa.gov/handbook.html (accessed on 2016).

42. BARSI J.A., SCHOTT J.R., PALLUCONI F.D., HOOK S.J. Validation of a web-based atmospheric correction tool for single thermal band instruments. Proceedings of SPIE - The International Society for Optical Engineering, 5882, 58820 E, 2005.

43. HAN L., DAI X., SHAO H., WANG H. An improved method for atmospheric transmissivity inversion based on field atmospheric modes. Remote Sensing for Land \& Resources, 28 (4), 88, 2016.

44. QIN Z., LI W., ZHANG M., KARNIELI A., BERLINER P. Estimating of the essential atmospheric parameters of mono-window algorithm for land surface temperature retrieval from Landsat TM 6. Remote Sensing for Land \& Resources, 56 (2), 37, 2003.

45. SOBRINO J.A., JIMENEZ-MUNOZ J.C., PAOLINI L. Land surface temperature retrieval from LANDSAT TM 5. Remote Sensing of Environment, 90 (4), 434, 2004.

46. LIU Y., PENG J., WANG Y. Diversification of land surface temperature change under urban landscape renewal: A case study in the main city of Shenzhen, China. Remote Sensing, 9 (9), 919, 2017

47. CARLSON T.N., RIPLEY D.A. On the relation between NDVI, fractional vegetation cover, and leaf area index. Remote Sensing of Environment, 62 (3), 241, 1997.

48. SOBRINO J.A., CASELLES V., BECKER F. Significance of the remotely sensed thermal infrared measurements obtained over a citrus orchard. ISPRS Journal of Photogrammetry and Remote Sensing, 44 (6), 343, 1990.

49. MAJUMDAR D.D., BISWAS A. Quantifying land surface temperature change from LISA clusters: An alternative approach to identifying urban land use transformation. Landscape and Urban Planning, 153, 51, 2016. 
50. GAO B. NDWI - A normalized difference water index for remote sensing of vegetation liquid water from space. Remote Sensing of Environment, 58, 257, 1996.

51. SUN Z., WANG C., GUO H., SHANG R. A modified normalized difference impervious surface index (MNDISI) for automatic urban mapping from Landsat imagery. Remote Sensing, 9 (9), 942, 2017.

52. EI-DERENY M., RASHWAN N.I. Solving multicollinearity problem using ridge regression models. Int.J.Contemp.Math.Sciences, 6 (12), 585, 2011.

53. ESTOQUE R.C., MURAYAMA Y., MYINT S.W. Effects of landscape composition and pattern on land surface temperature: An urban heat island study in the megacities of Southeast Asia. Science of the Total Environment, 577, 349, 2017.

54. XIAO F., LI Y., DU Y., LING F., YAN Y., FENG Q., BAN X. Monitoring perennial sub-surface waterlogged croplands based on MODIS in Jianghan plain, middle reaches of the Yangtze River. Journal of Integrative Agriculture, 13 (8), 1791, 2014.

55. ZHAO Z., HE B., LI L., WANG H., DARKO A. Profile and concentric zonal analysis of relationship between land use/land cover and land surface temperature: Case study of Shenyang, China. Energy and Buildings, 155, 282, 2017.

56. CAI Y., ZHANG H., PAN W., CHEN Y., WANG X. Urban expansion and its influencing factors in natural wetland distribution area in Fuzhou city, China. Chinese Geographical Science, 22 (5), 568, 2012.

57. CAI Y., ZHANG H., PAN W. Detecting urban growth patterns and wetland conversion processes in a natural wetlands distribution area. Polish Journal of Environment Studies, 24 (5), 1919, 2015 [In Polish].

58. FENG H., LIU H., WU L. Monitoring the relationship between the land surface temperature change and urban growth in Beijing, China. IEEE Journal of Selected Topics in Applied Earth Observations and Remote Sensing, 7 (10), 4010, 2014.

59. CAI Y., LI H., YE X., ZHANG H. Analyzing threedecadal patterns of land use/land cover change and regional ecosystem services at the landscape level: Case study of two coastal metropolitan regions, eastern China. Sustainability, 8 (8), 773, 2016.

60. GONG J., HU Z., CHEN W., LIU Y., WANG J. Urban expansion dynamics and modes in metropolitan Guangzhou, China. Land Use Policy, 72, 100, 2018.

61. ESTOQUE R.C., MURAYAMA Y. Intensity and spatial pattern of urban land changes in the megacities of Southeast Asia. Land Use Policy, 48, 213, 2015.

62. MCCONNELL V., WILEY K. Infill development: Perspectives and evidence from economics and planning. In The Oxford Handbook of Urban Economics and Planning; Brooks N., Donaghy K., Knaap G., Eds.; Oxford University Press: New York, USA, 473, 2011.

63. ZHANG X., ESTOQUE R.C., MURAYAMA Y. An urban heat island study in Nanchang City, China based on land surface temperature and social-ecological variables. Sustainable Cities and Society, 32, 557, 2017.

64. LU Y., FENG X., XIAO P., SHEN C. Urban heat island in summer of Nanjing based on TM data. Urban Remote Sensing Event, 1, 2009.

65. LIU Y., PENG J., WANG Y. Application of partial least squares regression in detecting the important landscape indicators determining urban land surface temperature variation. Landscape Ecology, 33 (7), 1133, 2018.

66. PENG J., MA J., LIU Q., LIU Y., HU Y., LI Y., YUE Y. Spatial-temporal change of land surface temperature across 285 cities in China: An urban-rural contrast perspective. Science of the Total Environment, 635, 487, 2018.

67. RUIZ M.A., SOSA M.B., Correa Cantaloube E.N., Canton M.A. Suitable configurations for forested urban canyons to mitigate the UHI in the city of Mendoza, Argentina. Urban Climate, 14, 197, 2015.

68. PENG J., JIA J., LIU Y., LI H., WU J. Seasonal contrast of the dominant factors for spatial distribution of land surface temperature in urban areas. Remote Sensing of Environment 215, 255, 2018. 
